\title{
PATTERNS OF LH AND PROLACTIN RELEASE FOLLOWING STEROID MANIPULATIONS IN THE RAT DURING DEVELOPMENT
}

\author{
E. PUIG-DURAN and Pamela C. B. MacKINNON, \\ Department of Human Anatomy, \\ University of Oxford (England.)
}

The effects of a single injection of $I \mu g$ oestradiol benzoate (OB) on serum luteinizing hormone $(\mathrm{L}, \mathrm{H})$ and prolactin (PRL) levels have been studied in groups of immature normal male and female Wistar rats, and in immature female rats which had received an injection (s.c.) of testosterone propionate $(1.25 \mathrm{mg}$ ) on the third day of life. This model has already been described (DöCKE and DöRNER, I965) ; however, the parameters observed were different. The animals were bred in our colony and kept under regulated lighting and temperature control. Serum LH and PRL, levels were measured by double antibody radioimmunoassays using an ovine-ovine system with NIH-LH-Sr3 standards (NISWENDER, Midgley, MonRoE and ReIChERT, I968) and a rat-rat system with NIAMDD-RP/I standards. The lower limits of sensitivity for the LH and PRL, assays were $0.25 \mathrm{ng} / \mathrm{ml}$ and $\mathrm{I} .95 \mathrm{ng} / \mathrm{ml}$ respectively. Blood was collected from the trunk following decapitation and serum samples were stored at $-20^{\circ} \mathrm{C}$ until assay.

Serum LH and PRL levels were measured at different time intervals over a 72-hour period after $O B$ was given at noon on the first experimental day (Day I) (table I). In 2I-day old females basal LH levels were either low or very high, but they were significantly reduced $(\mathrm{P}<0.05)$ to levels $<.25 \mathrm{ng} / \mathrm{ml}$ by $\mathrm{I} 8.00 \mathrm{~h}$ on Day I. LH levels remained low during the whole of Day 2 and the morning of Day 3. By $13.30 \mathrm{~h}$ they had started to increase and finally reached a peak ( $>30 \mathrm{ng} / \mathrm{ml}$; $\mathrm{P}<.00 \mathrm{I})$ at $\mathrm{I} 8.00 \mathrm{~h}$. Basal PRI, levels were all low $(<30 \mathrm{ng} / \mathrm{ml})$ but had started to increase by $\mathrm{I} 3.30 \mathrm{~h}$. on Day 2 , reaching a level of about roo $\mathrm{ng} / \mathrm{ml}$ at $\mathrm{I} 8.00 \mathrm{~h}$ on the same day. At $09.00 \mathrm{~h}$ on Day 3 , they were again low but by $13.30 \mathrm{~h}$ they had risen again to a peak ( $>300 \mathrm{ng} / \mathrm{ml}, \mathrm{P}<.00 \mathrm{I}$ ) at $\mathrm{I} 8.00 \mathrm{~h}$. Both the $\mathrm{LH}$ and the PRI, peaks were amenable to blocking by Nembutal injected between I3.00-I4.00 $\mathrm{h}$ on Day 3.

In 18-day old females $O B$ injection again eliminated the occurrence of high $\mathrm{LH}$ values but here levels remained low throughout the 3 -day test period. Although PRL levels were increased by $\mathrm{OB}$ treatment $(\mathrm{P}<.05)$ they never exceeded 

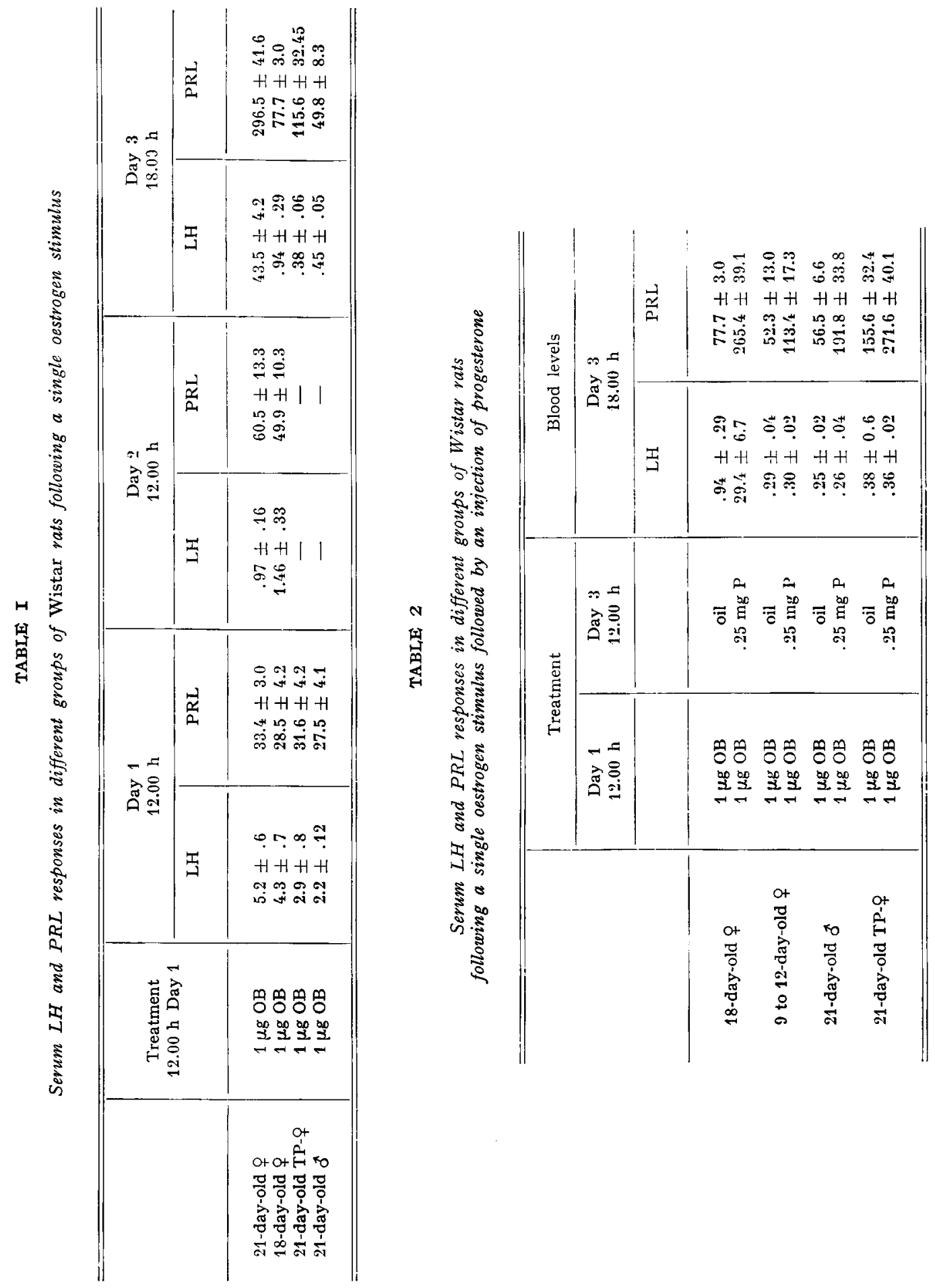
$75 \mathrm{ng} / \mathrm{ml}$. Immature males and androgenized females aged 2I days failed to show an increase in $\mathrm{LH}$ levels in response to $\mathrm{OB}$. However, androgenized females, but not males, showed a rise in PRL, levels in response to OB treatment which in timing corresponded to that shown by the normal 2 I-day old female, although the levels reached were somewhat lower.

The effect on serum $\mathrm{L} H$ and PRL levels of a single injection of $0.25 \mathrm{mg}$ of progesterone (PROG) given at noon on Day 3 after the preliminary priming dose of $\mathrm{OB}$ (I $\mu \mathrm{g}$ ) at noon on Day I was also studied in serum samples obtained from the three types of animals at $18.00 \mathrm{~h}$ on Day 3 (table 2). This regime provoked LH and PRL, responses in the I8-day old female which were equivalent to those seen in the $2 \mathrm{I}$-day old female stimulated only by $\mathrm{OB}$.

Female rats between 9-II days of age failed to show any increase in $\mathrm{LH}$ levels, even with the added PROG stimulas although PRI levels showed a small but significant $(\mathrm{P}<0.0 \mathrm{I})$ increase. The male and the androgenized female groups failed to show an increase in $\mathrm{LH}$ levels in response to treatment with $\mathrm{OB}$ and PROG, although PRL, levels were dramatically increased $(\mathrm{P}<0.00 \mathrm{I})$ by this treatment.

These studies suggest that the mechanisms involved with phasic LH release in the female develop and become sexually differentiated between 12 and 18 days of age, but that phasic PRL, release remains sexually undifferentiated.

\title{
Sexual Maturation, 3rd Workshop August 31, September 3, 1975.
}

\section{ACKNOWLEDGEMENTS}

We wish to acknowledge Dr. G. D. NISwENDER who provided the antibody for an ovine-ovine radioimmunoassay; The National Institute of Health for NIH-LH-SI 3 standard ; the NIAMDD for the FSH and prolactin kits with NIAMDD-FSH-I and NIAMDD-RP-I standards respectively ; the Medical Research Council for Grant No. G973/922B to PCBM; and the W. H. O. for financial support to EP-D.

\author{
RÉSUMÉ \\ IIBÉRATION DE LH E'T DE PROLACTINE \\ APRÈS INJECTION DE STÉROÏDES CHEZ LE RAT \\ AU COURS DU DÉVELOPPEMENT
}

L'injection de I $\mu$ g de benzoate d'estradiol provoque 3 jours plus tard une décharge de LH et de prolactine chez la Ratte impubère de 2 I jours, mais n'en provoque pas chez le Rat ou la Ratte androgénisée à la naissance. Une injection de $0,25 \mathrm{mg}$ de progestérone deux jours après l'estradiol permet de provoquer une décharge de $\mathrm{LH}$ et de prolactine chez la Ratte de $\mathrm{I} 8$ jours et une décharge de prolactine seule chez la Ratte de 12 jours et la Ratte androgénisée ou le mâle de $2 \mathbf{I}$ jours.

\section{REFERENCES}

Döcke F., Dörner G., 1965. The mechanism of the induction of ovulation by oestrogens. J. Endocr., 33, $49 \mathrm{I}-499$.

Niswender G. D., Midgley A. R. jr., Monroe S. E., Reichert L. E. jr., I968. Radioimmunoassay for rat luteinizing hormone with anti-ovine LH serum and ovine LH-131I. Proc. Soc. exp. Biol. Med., 128, 807-8I I. 